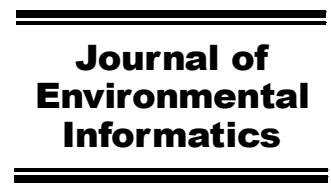

Www.iseis.org/jei

\title{
Fine Resolution Carbon Dioxide Emission Gridded Data and Their Application for China
}

\author{
B. F. Cai ${ }^{1}$, X. Q. Mao ${ }^{2 *}$, J. N. Wang ${ }^{1,3 *}$, and M. D. Wang ${ }^{2}$ \\ ${ }^{I}$ The Center for Climate Change and Environmental Policy, Chinese Academy for Environmental Planning, 8 Dayangfang, Beiyuan Road, \\ Chaoyang District, Beijing 100012, China \\ 2, School of Environment, Beijing Normal University, Beijing 100875, China \\ ${ }^{3}$ State Key Lab for Environmental Planning and Policy Stimulation, Beijing 100012, China
}

Received 26 October 2016; revised 21 June 2017; accepted 02 September 2017; published online 30 May 2018

\begin{abstract}
Based on the China National Pollution Source Census database that has been updated to 2012, and the China High Resolution Emission Gridded Data Version 1.0, a $1 \mathrm{~km} \times 1 \mathrm{~km}$ finer resolution emission gridded database of $\mathrm{CO}_{2}, \mathrm{CHRED} 2.0$, is developed. In the paper, the method, the data sources, a conceptual foundation for the data analysis, and an application in a spatial pattern analysis of $\mathrm{CO}_{2}$ emission for China are described. For the development of CHRED 2.0, the strict control of data quality and computing processes plays an important role in providing accurate data, highlightting the characteristics of high accuracy, direct verification, and indirect validation of essential data, mature and reliable mapping methods, and the precise spatial location of longitudinal and latitudinal data. The trial application of the China High Resolution Emission Gridded Data Version 2.0 proves its superiority in terms of reliability and suitability at the macro scale as well as at provincial-, city-, prefecture- and county-level $\mathrm{CO}_{2}$ emission estimations, spatial distribution analysis, and emission reduction plan making. The system is superior because the high-definition accuracy can split emissions between neighbor provinces, cities or counties, and the emission responsibility can be correctly allocated. Thus, the emission reduction plan and countermeasure can be established and taken in an environmentally rational and viable way.
\end{abstract}

Keywords: fine resolution gridded data, carbon dioxide, emission, China, CHRED 2.0

\section{Introduction}

High-resolution spatial data used to explore spatial patterns of carbon dioxide $\left(\mathrm{CO}_{2}\right)$ emissions has long been an important issue in international climate change mitigation circle. Europe and the United States have done leading research in $\mathrm{CO}_{2} / \mathrm{GHGs}$ emission grids and patterns (Gurney et al., 2009; Oda and Maksyutov, 2010; Gurney et al., 2012; European Commission, 2015).

High-resolution spatial carbon emission data is useful for identification of the carbon emission hotspots and the emission responsibility. Especially for countries like China, who are characterized with large territory and varied social-economic and natural conditions, and the varied data sources and data treatment methodologies across different provinces and regions, and very poor data comparability, such high resolution data sets are of more importance. Using spatialized and high-resolution visual data produced with the uniform standard, it is easier to directly perceive the emission spatial chara-

${ }^{*}$ Corresponding author. Tel.: +86 10 58807812; fax: +86 1082025600. E-mail address: maoxq@bnu.edu.cn (X.Q. Mao).

ISSN: $1726-2135$ print/1684-8799 online

(C) 2019 ISEIS All rights reserved. doi:10.3808/jei.201800390 cteristics, and convenient for the decision makers and carbon emission reduction planners to allocate emission reduction resources and efforts, either at national, provincial, city or county level. On the other hand, with the accumulation of remote sensing satellites data from GOSAT (and the to be launched GOSAT-2) and OCO-2 program launched by Japan, and the TanSat launched by China in 2016, high-resolution spatial emission data will be used as the earth surface emission background to verify and calibrate the column carbon concentration (monitored by the satellites) through inverse algorithm.

To meet an increasing demand for high-resolution $\mathrm{CO}_{2}$ emission maps, researchers and practitioners have recently opted for high quality emission data based on bottom-up approaches that rely on district $\mathrm{CO}_{2}$ emission monitoring, reporting, and checking (Oda and Maksyutov, 2010; Zhao et al., 2012; Wang et al., 2014).

Numerous studies have developed $\mathrm{CO}_{2}$ emissions grids on global, regional, and national scales (Gurney et al., 2009; Rayner et al., 2010; Andres et al., 2012; Asefi-Najafabady et al., 2014; Cai and Zhang, 2014). The methods used in these studies can be generally categorized into top-down and bottom-up approaches (IPCC, 2014).

In a top-down approach, aggregated emissions data is downscaled in accordance with socio-economic data (van Vuuren 
et al., 2010). This approach assumes that $\mathrm{CO}_{2}$ emissions relate quantitatively to socio-economic activity, and thus socio-economic characteristics may act as proxies for emissions. Population density (Andres et al., 1996; Olivier et al., 2005) and nighttime light imagery of the Defense Meteorological Satellite Program's Operational Linescan System (DMSP/ OLS) (Andres et al., 1996; Doll et al., 2000; Meng et al., 2014) are the two most widely used approaches to estimate and spatially locate $\mathrm{CO}_{2}$ emissions. However, due to data quality issues with DMSP/OLS data (Elvidge et al., 2014), Doll et al. (2000) found that intra-country spatial correlation of estimated emissions was not as strong for developing countries as for developed countries. Thus, top-down approaches to estimate emissions in developing countries such as China may prove to be less reliable. Moreover, empirical findings suggest that topdown approaches may result in an error rate of approximately $50 \%$ per pixel, and these errors are spatially correlated (Rayner et al., 2010). Furthermore, emissions from industrial and transportation sectors are often underestimated by top-down approaches based on socio-economic data (Ghosh et al., 2010) because large emission sources (e.g., coal-fired power plants) might be located in less populated areas or fail to emit detectable light. Thus, a top-down approach is preferred when finer scale data are not available.

When detailed emission data are available, a bottom-up approach is preferred as it provides more accurate emission mapping, especially at smaller spatial scales (Kennedy et al., 2010; Gurney et al., 2012; Wang et al., 2012). An earlier attempt to estimate $\mathrm{CO}_{2}$ emissions through a bottom-up approach in China considered data on power plants, though this attempt yielded a coarse spatial resolution at $0.25 \times 0.25^{\circ}$ (roughly $25 \mathrm{~km} \times 25 \mathrm{~km}$ ) (Zhao et al., 2008; Zhao et al., 2012). The Emission Database for Global Atmospheric Research (EDGAR) (Olivier et al., 2012) and the Fossil Fuel Data Assimilation System (FFDAS) (Rayner et al., 2010; Asefi-
Najafabady et al., 2014), both based on bottom-up approaches using point source emissions, have provided finer resolution $\mathrm{CO}_{2}$ emissions data at $0.1 \times 0.1^{\circ}$ (roughly $10 \mathrm{~km} \times 10 \mathrm{~km}$ ) for China.

More recently, the first National Pollution Source Census (NPSC) database, which contains information on 1.58 million officially registered enterprises, facilities' emission and fuel consumption details, and accurate geographic coordinates in China, allowed for the development of the China High Resolution Emission Gridded Data Version 1.0 (CHRED 1.0). CHRED 1.0 provides a $10 \mathrm{~km} \times 10 \mathrm{~km}$ spatial resolution for China's $\mathrm{CO}_{2}$ emissions (Wang et al., 2014). To date, it is the most accurate and thorough bottom-up quantitative and spatial $\mathrm{CO}_{2}$ emission dataset for China.

Although CHRED 1.0 has largely met and satisfied the demand of spatial pattern analysis for $\mathrm{CO}_{2}$ emission reduction and management plans at national and regional levels, the $10 \mathrm{~km}$ spatial resolution is still too coarse at levels of county, prefecture, and province. Managing carbon sources requires emission map at finer spatial resolutions. Here, we show the development of CHRED 2.0, a $1 \mathrm{~km} \times 1 \mathrm{~km}$ finer resolution emission gridded database for $\mathrm{CO}_{2}$, and its trial applications for China.

\section{Methods and Data}

\subsection{Data Sources}

Emissions from industrial enterprises comprise the majority of $\mathrm{CO}_{2}$ emissions in China (Wang et al., 2014). For this study, the detailed data on the various types of industrial facilities was drawn from the China National Pollution Source Census (NPSC) database (Wang et al., 2014). This database was constructed from 2007 data and subsequently updated using 2012 industrial enterprise-level data based on China's environmental statistics (NBS and MEP, 2013). This detailed dataset provides facility-specific information of fossil fuel

Table 1. Summary of Data Sources Used in this Study

\begin{tabular}{|c|c|c|c|c|}
\hline $\begin{array}{l}\mathrm{CO}_{2} \\
\text { emissions } \\
\text { sources }\end{array}$ & Sectorial data & $\begin{array}{l}\text { Spatial } \\
\text { resolution }\end{array}$ & Description & Data sources \\
\hline \multirow{3}{*}{$\begin{array}{l}\text { Energy } \\
\text { activities }\end{array}$} & Industry & $\begin{array}{c}\text { Point } \\
\text { sources }\end{array}$ & $\begin{array}{l}\text { The detailed data of industrial facilities of } \\
\text { various types of industrial enterprises are } \\
\text { provided. Data quality is checked by cross } \\
\text { verification, including logical analysis, } \\
\text { statistical analysis and macro-economic data. }\end{array}$ & $\begin{array}{l}\text { China industrial } \mathrm{CO}_{2} \text { point emissions } \\
\text { data set inferred from the National } \\
\text { Pollution Source Census (NPSC) } \\
\text { database and its dynamically } \\
\text { updating system, environmental } \\
\text { statistics database, field survey data, } \\
\text { industrial statistic data. }\end{array}$ \\
\hline & $\begin{array}{c}\text { Agriculture } \\
\text { production/rural } \\
\text { household consumption }\end{array}$ & Provinces & $\begin{array}{l}\text { Agriculture/rural energy use data is used to } \\
\text { calculate provincial agriculture/rural } \mathrm{CO}_{2} \\
\text { emission }\end{array}$ & $\begin{array}{l}\text { China Energy Statistical Yearbook } \\
(\mathrm{NSB}, 2015)\end{array}$ \\
\hline & Transport & Provinces & $\begin{array}{l}\text { Transport } \mathrm{CO}_{2} \text { emissions from Chinese } \\
\text { provinces, including road, railway, water and air } \\
\text { transports. }\end{array}$ & $\begin{array}{l}\text { China Energy Statistical Yearbook } \\
\text { (NSB, 2015) }\end{array}$ \\
\hline \multirow[t]{2}{*}{$\begin{array}{l}\text { Social- } \\
\text { economic } \\
\text { processes }\end{array}$} & $\begin{array}{l}\text { Spatial population } \\
\text { distribution }\end{array}$ & $1 \mathrm{~km}$ & $\begin{array}{l}\text { LandScan is developed by Oak Ridge National } \\
\text { Laboratory (ORNL). It is the finest resolution } \\
\text { global population distribution dataset available } \\
\left(30^{\prime \prime} \times 30^{\prime \prime} \text { globally, and about } 1 \mathrm{~km}^{2} \text { in China). }\right.\end{array}$ & LandScan data set \\
\hline & $\begin{array}{c}\text { Urban construction land } \\
\text { Rural residents land }\end{array}$ & $30 \mathrm{~m}$ & Land use data & Globeland30-2010 \\
\hline
\end{tabular}


consumption, geographic coordinates (latitude and longitude), administrative properties, addresses, products, production technology, kiln and boiler, and other data. The data quality was checked through cross verification, including logical analysis between different indicators and statistical analysis between facility and macro-economic data. Abnormal data were identified and revised after data verification.

The same methods as Cai et al. (2012) was used, with data updated to the year of 2012, to calculate transport energy use data. This study considers transporting $\mathrm{CO}_{2}$ emissions from road, railway, water, and air transports, from Chinese provinces, with data sourced from China Energy Statistical Yearbook (NSB, 2015).

Fossil fuel consumptions from agriculture, rural and urban households were also inferred from China Energy Statistical Yearbook (NBS, 2015). For this study, LandScan (Bhaduri et al., 2007), coupled with land cover data from GlobeLand30
(National Geomatics Center of China, 2014), were used to spatially allocate emissions from Chinese urban and rural households.

Data sources and their resolutions are shown in Table 1, which demonstrates how the Chinese industrial facility $\mathrm{CO}_{2}$ point emission database, inferred from the NPSC database and its continually updated system, lays the foundation for the calculation and spatial mapping of $\mathrm{CO}_{2}$ emissions. A sketch map of all the spatial data sources is shown in Figure 1.

\section{2. $\mathrm{CO}_{2}$ Emissions Accounting}

Calculation of $\mathrm{CO}_{2}$ emissions complies with the Guidelines on Building Provincial GHGs Emissions Inventory of China (National Development and Reform Commission, 2011). Emission source classification is mainly based on the National Pollution Source Census (NPSC). The IPCC guidelines and the GHG Inventory in the Second Communication

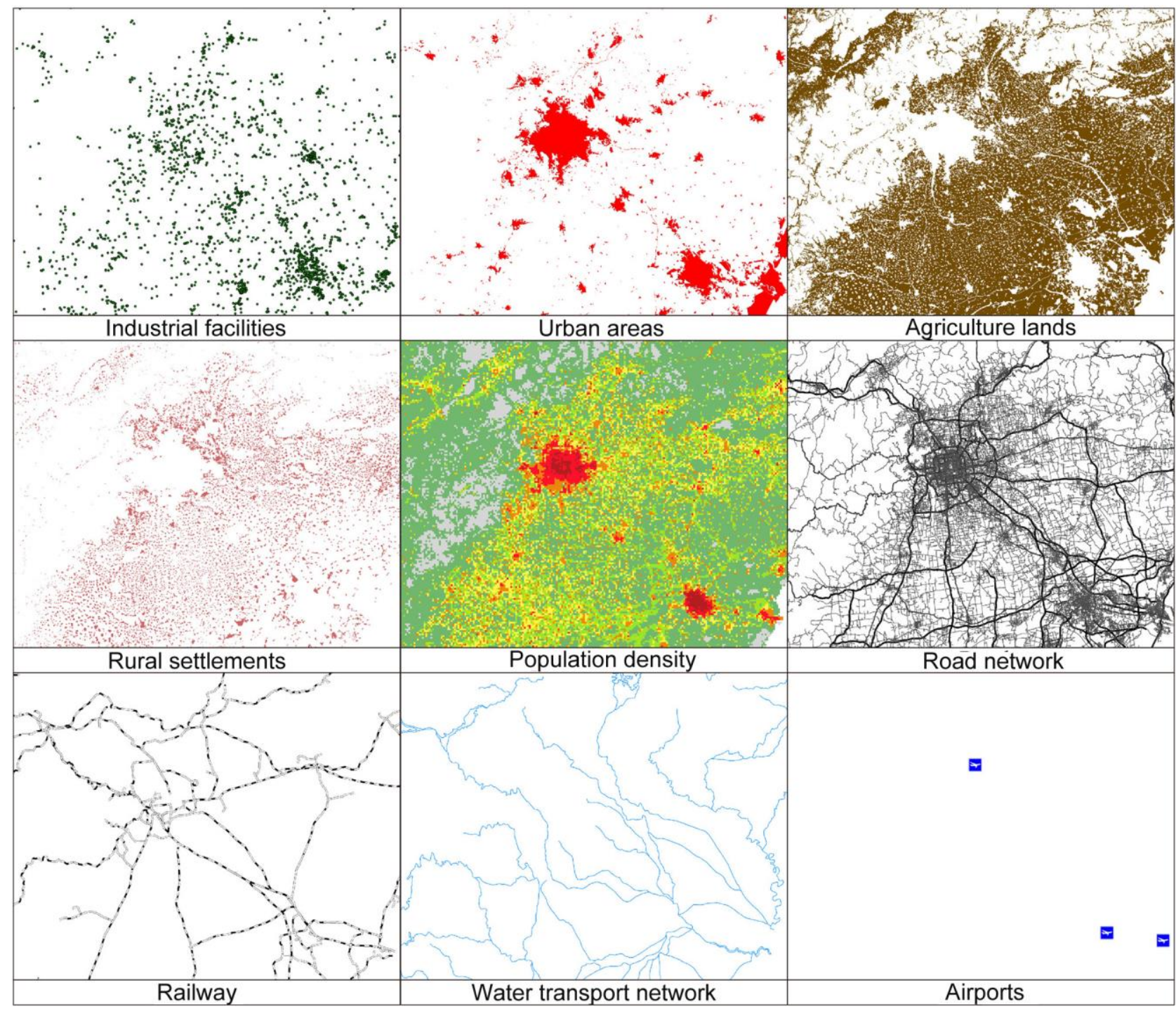

Figure 1. Sketch map of the spatial data sources to map $\mathrm{CO}_{2}$ emissions in the sample areas of China (Beijing and the surrounding areas). 
on Climate Change of China were referred to for emission factors and the accounting system (National Development and Reform Commission, 2013, 2014). $\mathrm{CO}_{2}$ emissions from landuse change and forestry are not within the scope of the present study. $\mathrm{CO}_{2}$ emissions of industrial enterprises was calculated by summing up emissions from the combustion of fossil fuels and industrial processes (Equation (1)):

$\mathrm{E}=\sum M_{\text {fuel }} \times F_{\text {fuel }}+E_{p}$

where $E$ is $\mathrm{CO}_{2}$ emissions of an enterprise, $M_{\text {fuel }}$ is energy use of a specific fuel, $F_{f u e l}$ is the $\mathrm{CO}_{2}$ emission factor for a specific fuel, and $E_{p}$ represents $\mathrm{CO}_{2}$ emissions from industrial processes.

For $\mathrm{CO}_{2}$ emissions from the industrial processes, only production of clinker, lime, and iron and steel are considered.
Industrial emission factors are inferred from the National Development and Reform Commission (2014) and the main outcome from the Second National Communication on Climate Change of China, which contains detailed and officially recognized emission factors for different industries in terms of energy type and combustion equipment in different regions.

\subsection{Methods of Downscaling and Combining Various of Streams of Data for a Finer Resolution of Carbon Emission}

Spatial mapping is achieved through a bottom-up approach. This approach allows for a fine spatial resolution of 1 $\mathrm{km} \times 1 \mathrm{~km}$ by combining information from point sources and gridded area sources. Figure 2 illustrates the protocol of compiling the $1 \mathrm{~km} \times 1 \mathrm{~km}$ resolution gridded $\mathrm{CO}_{2}$ emissions data.

This study refines the previous studies of the research team of Wang et al. (2014) through the following manipu-

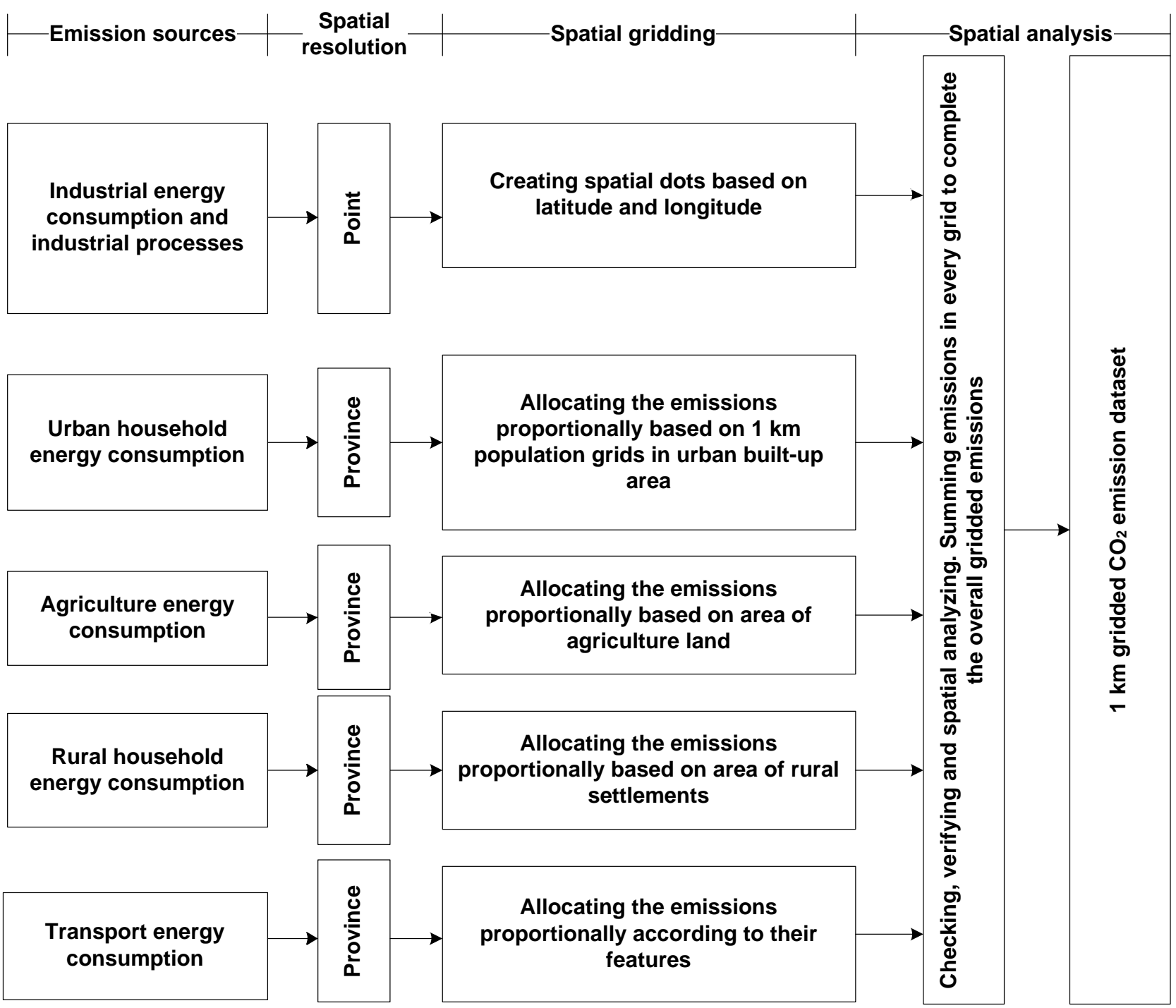

Figure 2. A schematic of the spatial mapping of $1 \mathrm{~km} \times 1 \mathrm{~km}$ gridded $\mathrm{CO}_{2}$ emissions. 
lations. First, a base map of fishnet grids of China at $1 \mathrm{~km} \times 1$ $\mathrm{km}$ resolution using the Krasovsky 1940 Albers Projected Coordinate System was created.

For the point emission sources in the industrial sector, dots based on their coordinates with values of $\mathrm{CO}_{2}$ emissions (from both energy consumption and industrial process) were created and the $\mathrm{CO}_{2}$ emissions of dots that were within each cell of the $1 \mathrm{~km} \times 1 \mathrm{~km}$ fishnet grids were summed. The accuracy of the spatial location of industrial enterprises was verified through employing dual-control of spatial accuracy of point emission sources based on both the geographic coordinates and reversed geocoding from facilities' registered addresses. High-resolution Google Earth images were used when necessary to visually reconfirm the positions of some facilities with large emissions by locating the emissions stack or cooling tower.

In the previous study (Wang et al., 2014), $\mathrm{CO}_{2}$ emissions from agriculture/rural household energy consumption were calculated at the provincial level based on the data from China Energy Statistical Yearbook and were then allocated evenly to grid cells in the corresponding provinces. For the present study, the spatialization of emissions from agriculture and rural households' energy consumption was enhanced by integrating information on human settlements drawn from remote sensing image and population density data.

The urban residential energy consumption consisting of energy use from hotels, restaurants, hospitals, schools, and household energy use (heating and/or cooling and cooking) were also drawn from the updated China Pollution Source Census (CPSC). The residential energy consumption was surveyed at the county/district level. The urban household energy use was determined by sampling conducted in every town, and then the average level was multiplied by the population of the districts/counties. The $\mathrm{CO}_{2}$ emissions in urban residential sector were made spatially explicit by allocating the $\mathrm{CO}_{2}$ emissions in each county/district proportionally based on the $1 \mathrm{~km} \times 1 \mathrm{~km}$ population grids.

In the previous work (Wang et al., 2014), the transport $\mathrm{CO}_{2}$ emissions including emissions from road, railway, water, and aviation, were allocated to each province proportionally to the $10 \mathrm{~km} \times 10 \mathrm{~km}$ population grid cells. In the present study, emission data associated with transportation were refined through accounting traffic flow and length density for road, rail, navigation, and aviation (airports). $\mathrm{CO}_{2}$ emissions from road transportation were allocated into each $1 \mathrm{~km} \times 1$ $\mathrm{km}$ grid in proportion to grade-weighted road length density. Different grades of road refer to different degrees of designed traffic volume. In addition, street traffic volume was fully taken into consideration. Similarly, $\mathrm{CO}_{2}$ emissions of rail and water transportation were allocated into each grid in proportion to railway and water way densities, respectively, while $\mathrm{CO}_{2}$ emissions of aviation were allocated equally to airports in each province.

Similar to the previous study (Wang et al., 2014), the $\mathrm{CO}_{2}$ emissions from the industrial sector, agriculture/rural household sector, urban residential sector, and transport sector in every grid were summed to complete the gridded $\mathrm{CO}_{2}$ emissions:
$E_{i, j}=\sum E_{i, j}^{I N D E}+E_{i, j}^{I N D P}+E_{i, j}^{A G}+E_{i, j}^{S V}+E_{i, j}^{\text {Trans }}+E_{i, j}^{U b}+E_{i, j}^{R u}$

where $E_{i, j}$ is the total emission from grid $i, j, E_{i, j}^{I N D E}, E_{i, j}^{I N D P}$, $E_{i, j}^{A G}, E_{i, j}^{S V}, E_{i, j}^{\text {Trans }}, E_{i, j}^{U b}, E_{i, j}^{R u}$ represents emissions from industrial energy, industrial process, agricultural, service, transport, rural and urban emissions, respectively.

After the improvement and downscaling manipulation, the spatialized $\mathrm{CO}_{2}$ emissions of the current product combined and merged several streams of data and were refined to much higher resolution.

\section{Trial Application}

\subsection{Spatial Pattern Analysis of $\mathrm{CO}_{2}$ Emission of Key Industrial Sectors}

Due to the dominant proportion of industrial emissions in the national total, spatial pattern of $\mathrm{CO}_{2}$ emission of key industrial sectors is decisive to the nation-wide $\mathrm{CO}_{2}$ emission situation. Kernel density is a non-parametric method to estimate the probability density function of a variable. In this study, we used the Kernel density model to explore the spatial characteristics of $\mathrm{CO}_{2}$ emissions from key industrial sectors. Through calculating the magnitude of $\mathrm{CO}_{2}$ emissions from industrial enterprises per unit area, the Kernel density model identifies hotspots, or "gravity center", and gradient spatial distribution of $\mathrm{CO}_{2}$ emissions from key industrial sectors.

Spatial patterns of $\mathrm{CO}_{2}$ emissions from coal-fired power plants are shown in Figure 3. Although coal-fired power plants are distributed across North and South China, the Kernel density spatial map of $\mathrm{CO}_{2}$ emissions (Figure 3 (b)) shows that East China and North China contain heavy emission centers, while Northwest, Southwest and Northeast China contain scattered emission spots. High emission centers include major coal production and coal-fired power generation and supply areas, such as North Shanxi-Erdos of Inner Mongolia, East Ningxia, North Henan, South Shandong-North Jiangsu, North Guizhou, etc., as well as the coal consumption and coal-fired power generation and consumption regions, such as Jing-Jin-Ji, Yangtze River Delta, Pearl River Delta, and Central Liaoning regions.

The Kernel density spatial map of emissions of power plants (Figure 3 (b)) also highlights cities identified as hotspots or emission gravity centers, including Shuozhou, Datong, Yinchuan, Shizuishan, Jiaozuo, Zhengzhou, Luoyang, Zaozhuang, Jining, Xuzhou, Tianjin, Shanghai, Wuxi, Suzhou, Bijie, and Guangzhou. All these cities are either economically developed or rich in coal resources and major suppliers and producers of coal for China. Thus, the Kernel spatial pattern closely coincides with the spatial characteristics of the country's resources and economic development.

Figure 4 (a) illustrates the emissions of cement facilities. Unlike coal-fired power plants, cement production resources, namely limestone, can be found across China and transporttation distance for cement facilities are much more evenly distributed spatially within the territory. However, from west to east, a distinct increase in Kernel density can be observed 

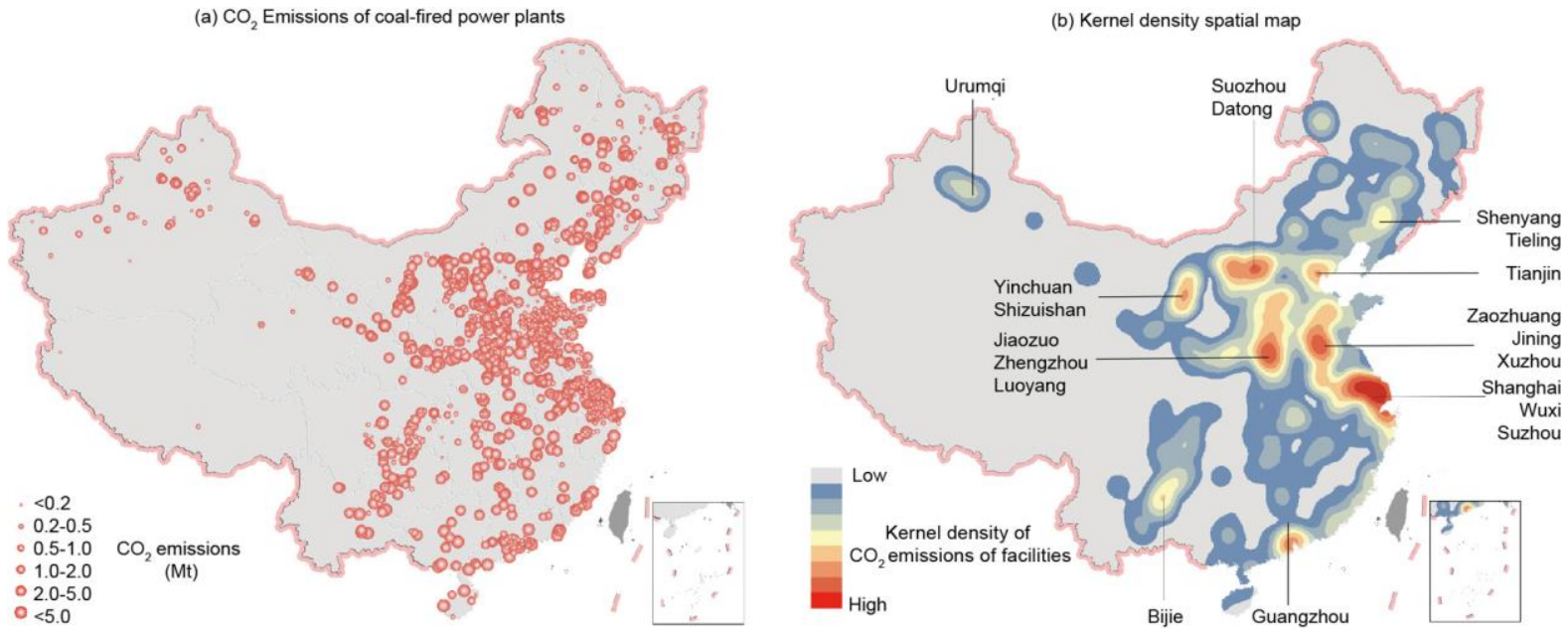

Figure 3. Spatial pattern of $\mathrm{CO}_{2}$ emissions from coal-fired power plants: (a) $\mathrm{CO}_{2}$ emissions of coal-fired power plants; (b) Kernel density spatial map of $\mathrm{CO}_{2}$ emissions of coal-fired power plants.

(a) $\mathrm{CO}_{2}$ Emissions of cement facilities

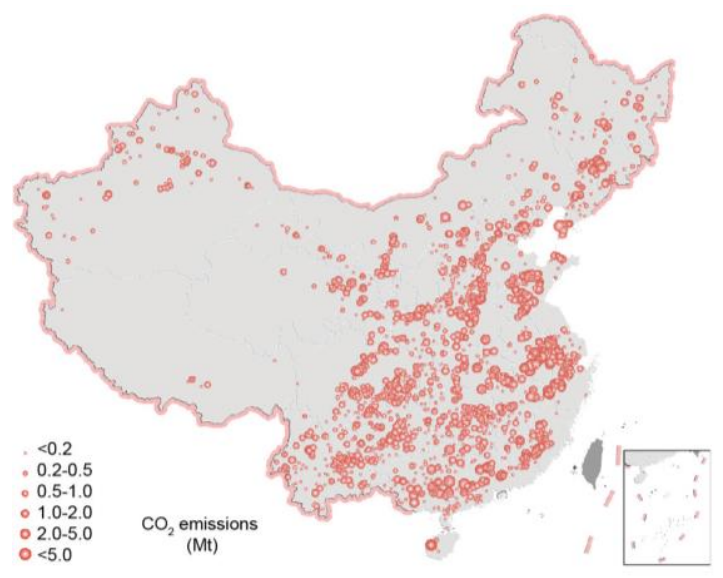

(b) Kernel density spatial map

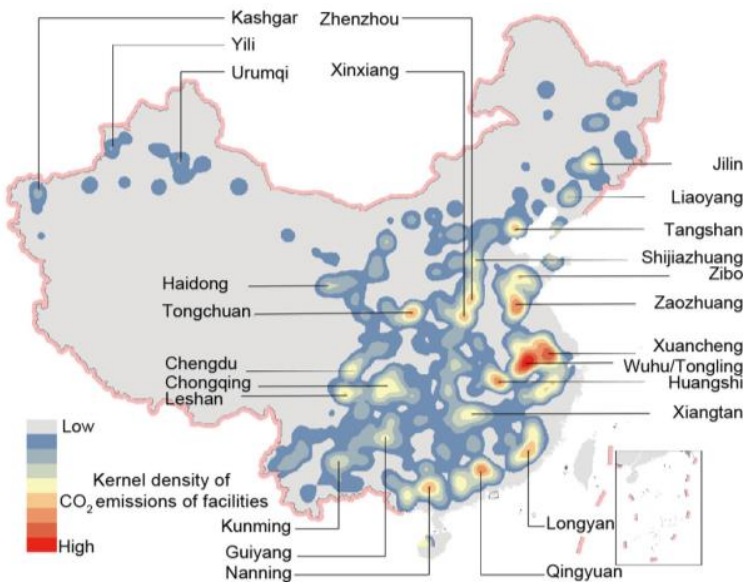

Figure 4. Spatial pattern of $\mathrm{CO}_{2}$ emissions from cement facilities: (a) $\mathrm{CO}_{2}$ emissions of cement facilities; (b) Kernel density spatial map of $\mathrm{CO}_{2}$ emissions of cement facilities.
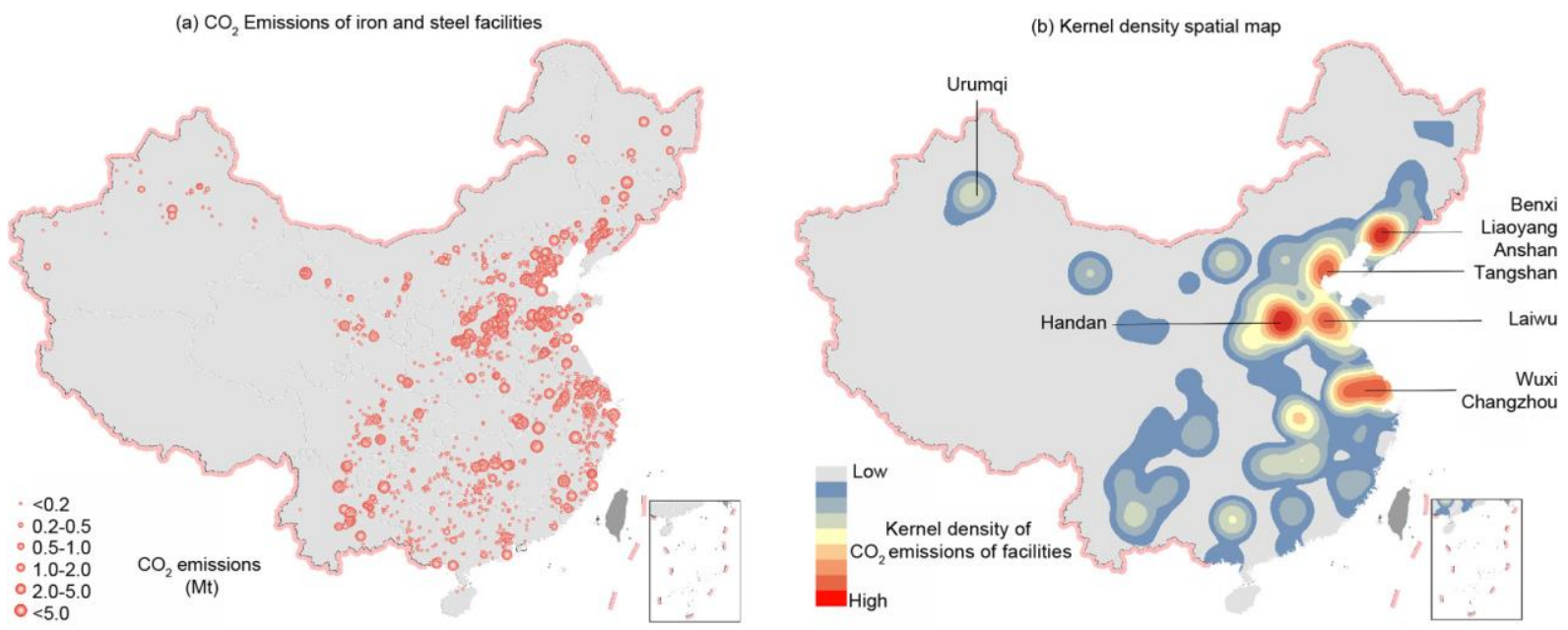

Figure 5. Spatial pattern of $\mathrm{CO}_{2}$ emissions from iron and steel facilities: (a) $\mathrm{CO}_{2}$ emissions of iron and steel facilities; (b) Kernel density spatial map of $\mathrm{CO}_{2}$ emissions of iron and steel facilities. 
(Figure 4 (b)). In the Yangtze River Delta, Pearl River Delta, and other coastal areas, the density is much higher than in other parts of China where high emission sources that discharge 2.0 to $5.0 \mathrm{Mt}$ per year appear frequently and comprise main components of the eastern region. Emission gravity centers appear in and around the cities such as Zaozhuang, Zhengzhou, Xinxiang, Tongchuan, Wuhu/Tongling, Xuancheng, Huangshi, Nanning, Qingyuan, Longyan, and others.

Comparatively, the Kernel density of $\mathrm{CO}_{2}$ emissions for iron and steel facilities is unevenly distributed (Figure 5). The regional differentiation between west and east of China is distinct. High Kernel density areas center around such cities as Liaoyang, Benxi, Anshan, Tangshan, Handan, Laiwu, Wuxi, and Changzhou. These emission gravity centers, especially those located around the Jing-Jin-Ji area, have a remarkable influence on the emissions of traditional local air pollutants such as $\mathrm{SO}_{2}, \mathrm{PM}_{2.5}$, NOx, etc., and thus impact the air quality of the surrounding area.

\subsection{Spatial Pattern Analysis of $\mathrm{CO}_{2}$ Emissions at Different Levels of Administrative Divisions}

\subsubsection{Spatial Pattern Analysis at The National Level}

Figure 6 shows the gridded $\mathrm{CO}_{2}$ emissions map with emission data updated to 2012. The overall spatial pattern of $\mathrm{CO}_{2}$ emissions in China observed from this map does not show much difference compared with that of the previous $10 \mathrm{~km} \times$ $10 \mathrm{~km}$ resolution gridded $\mathrm{CO}_{2}$ emission map with the 2007 data sets (Wang et al., 2014). The emissions in the eastern part of China are obviously higher than those in Western China. Within the eastern region, the $\mathrm{CO}_{2}$ emissions in and around key cities (e.g., Beijing, Shanghai, Wuhan, Zhengzhou, and Guangzhou) are much higher than other regions. Within the western region, large cities such as Chongqing, Chengdu and Xi'an and their surrounding areas are emission hotspots. The JingJin-Ji region, the Yangtze River Delta region, and the Pearl River delta regions are peak areas of $\mathrm{CO}_{2}$ emission in China.

However, on closer observation, the $1 \mathrm{~km} \times 1 \mathrm{~km}$ resolution $\mathrm{CO}_{2}$ emission map, when compared with the $10 \mathrm{~km} \times$ $10 \mathrm{~km}$ resolution map, has a much smoother color transition, especially for the eastern part of China. This essentially indicates a much finer spatial resolution of $\mathrm{CO}_{2}$ emission in the map, which is expressed by much richer gradation of the emission quantity. A disclosure of more detailed spatial distribution facts of $\mathrm{CO}_{2}$ emission is of interest especially for a 'zoom in' study to the highly and densely $\mathrm{CO}_{2}$ emitting areas. In looking at the western parts of China and especially Northwestern China, many line traces reflect the $\mathrm{CO}_{2}$ emissions from transportation routes. Also in the western parts of China, there are large white or blank areas that convey no human habitation in a vast, remote, uninhabited areas, and thus no human activity induced $\mathrm{CO}_{2}$ emissions.

Figure 7 shows a comparison of the cumulative curves of the grid cells contribution to total emission of China, for the 1 $\mathrm{km} \times 1 \mathrm{~km}$ and $10 \mathrm{~km} \times 10 \mathrm{~km}$ resolution maps. Though both curves illustrate a high degree of emission clustering, the curve of the $1 \mathrm{~km} \times 1 \mathrm{~km}$ resolution map indicates that $1 \%$ of total land accounts for about $94 \%$ of the total $\mathrm{CO}_{2}$ emission. Regulating $0.1 \%$ of total land territory could enable the management of roughly $85 \%$ of emissions in China. In comparison, estimations from the previous $10 \mathrm{~km} \times 10 \mathrm{~km}$ resolution maps (Wang et al., 2014) indicated that regulating 1\% of total land could only enable the management of $70 \%$ of emissions in China. These findings could help central and local governments to more accurately target emission reduction efforts and resources for these top $0.1 \%$ grid cells in order to optimize results from reduction efforts.

\subsubsection{Spatial Pattern Analysis at Regional and Provincial Levels: Yangtze River Delta and Zhejiang Province}

Intuitively, the fine resolution map is more accurate and suitable for smaller scale analyses of $\mathrm{CO}_{2}$ emission spatial patterns and can provide much stronger support for regional, provincial, city (or prefecture), and county level studies.

Taking the Yangtze River Delta region as an example, a comparison of the $1 \mathrm{~km} \times 1 \mathrm{~km}$ and $10 \mathrm{~km} \times 10 \mathrm{~km}$ resolution $\mathrm{CO}_{2}$ emission distribution maps is shown in Figure 8.

From the $10 \mathrm{~km} \times 10 \mathrm{~km}$ resolution $\mathrm{CO}_{2}$ emission distribution map (Figure 8 (b)), it is observed that the high emission area is surrounding and to the east of Taihu Lake. However, the high emission grids with emission of over 100,000 ton/a appear closely together; each of the grids is hard to identify and assign to a city or prefecture, such as Shanghai, Hangzhou, Nanjing, Ningbo, Changzhou or Suzhou, etc. Even the grids of the Taihu Lake water surface are marked with colors representing quite high $\mathrm{CO}_{2}$ emission, which contradicts the fact. This is due to the fact that each grid is too large (100 $\mathrm{km}^{2}$ ) and often extends across different administrative and natural geography boundaries. This essentially indicates that a $10 \mathrm{~km} \times 10 \mathrm{~km}$ resolution $\mathrm{CO}_{2}$ emission distribution map is not suitable for or supportive of local emission management.

The $1 \mathrm{~km} \times 1 \mathrm{~km}$ resolution $\mathrm{CO}_{2}$ emission map (Figure 8 (a)) gives a much clearer picture of $\mathrm{CO}_{2}$ emission distribution locally. Emission hotspots (high emission grids) are mostly located in key cities such as Shanghai, Hangzhou, Nanjing, Ningbo, Changzhou, Suzhou, etc., where there the annual $\mathrm{CO}_{2}$ emission per $\mathrm{km}^{2}$ can reach 100,000 tons or more. The spatial distribution of $\mathrm{CO}_{2}$ emissions in the Yangtze River Delta region shows three gradients: Shanghai, as the economic core of Yangtze River Delta, lies at the highest level; the second level comprises surrounding cities, such as Changzhou, Wuxi, Huzhou, Hangzhou, Shaoxing and Ningbo etc.; areas outside of the first and second level form the third level in the picture of $\mathrm{CO}_{2}$ spatial distribution. Cities like Nanjing, Yangzhou, Taizhou, Xuzhou, Lianyungang, Suqian, Quzhou, Jinhua and Wenzhou are featured with scattered larger emission grids, but relatively lower emission levels. There are many filiform lines connecting high emission spots that are roads, railways and waterways. The vast rural area, mainly comprised of farm land and water surface, forms the grey background in the image. This image accurately reflects the distribution of $\mathrm{CO}_{2}$ 
(a) $10 \mathrm{~km} \times 10 \mathrm{~km}$ resolution gridded $\mathrm{CO}_{2}$ emission map (2007)

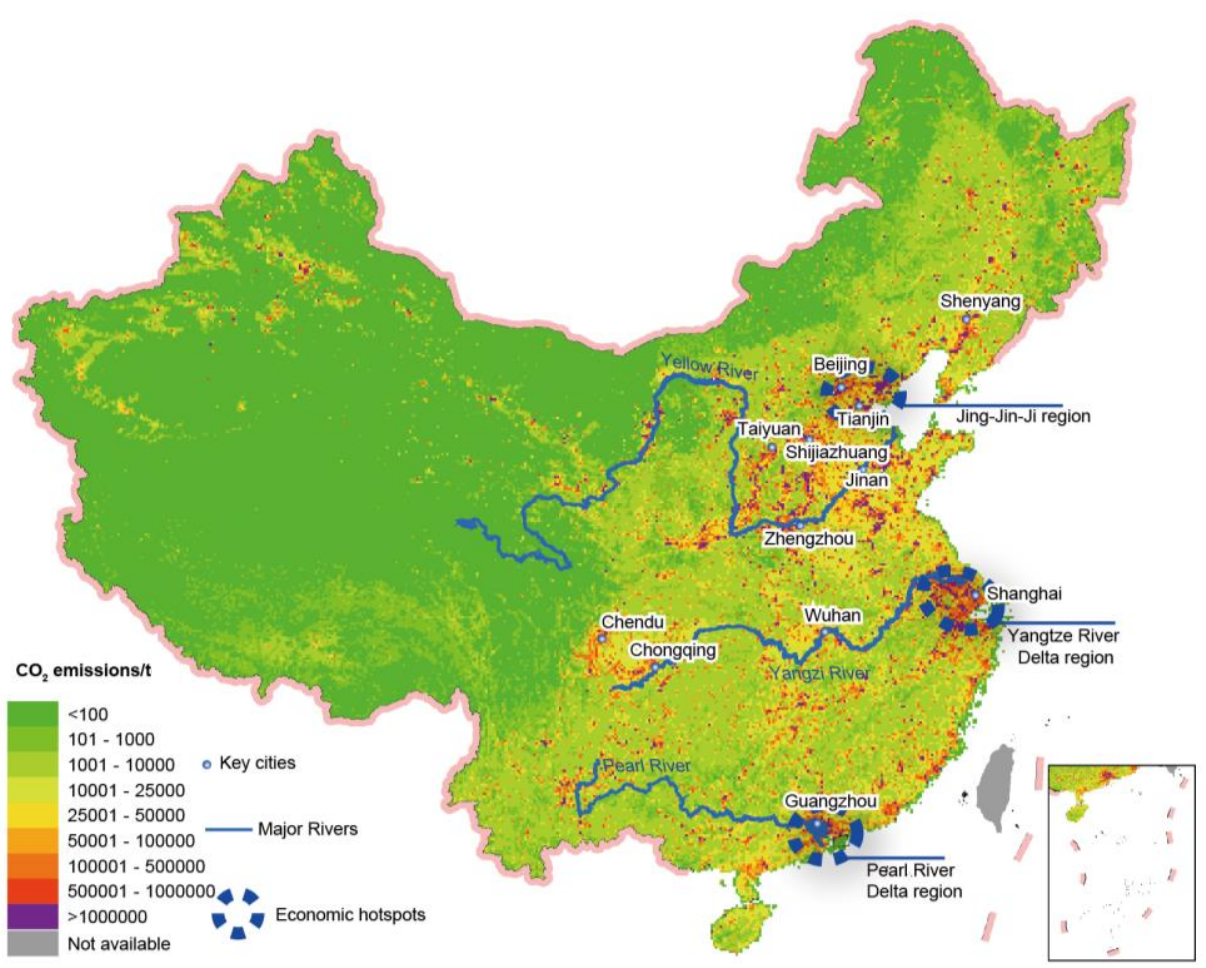

(b) $1 \mathrm{~km} \mathrm{X} 1 \mathrm{~km}$ resolution gridded $\mathrm{CO}_{2}$ emission map (2012)

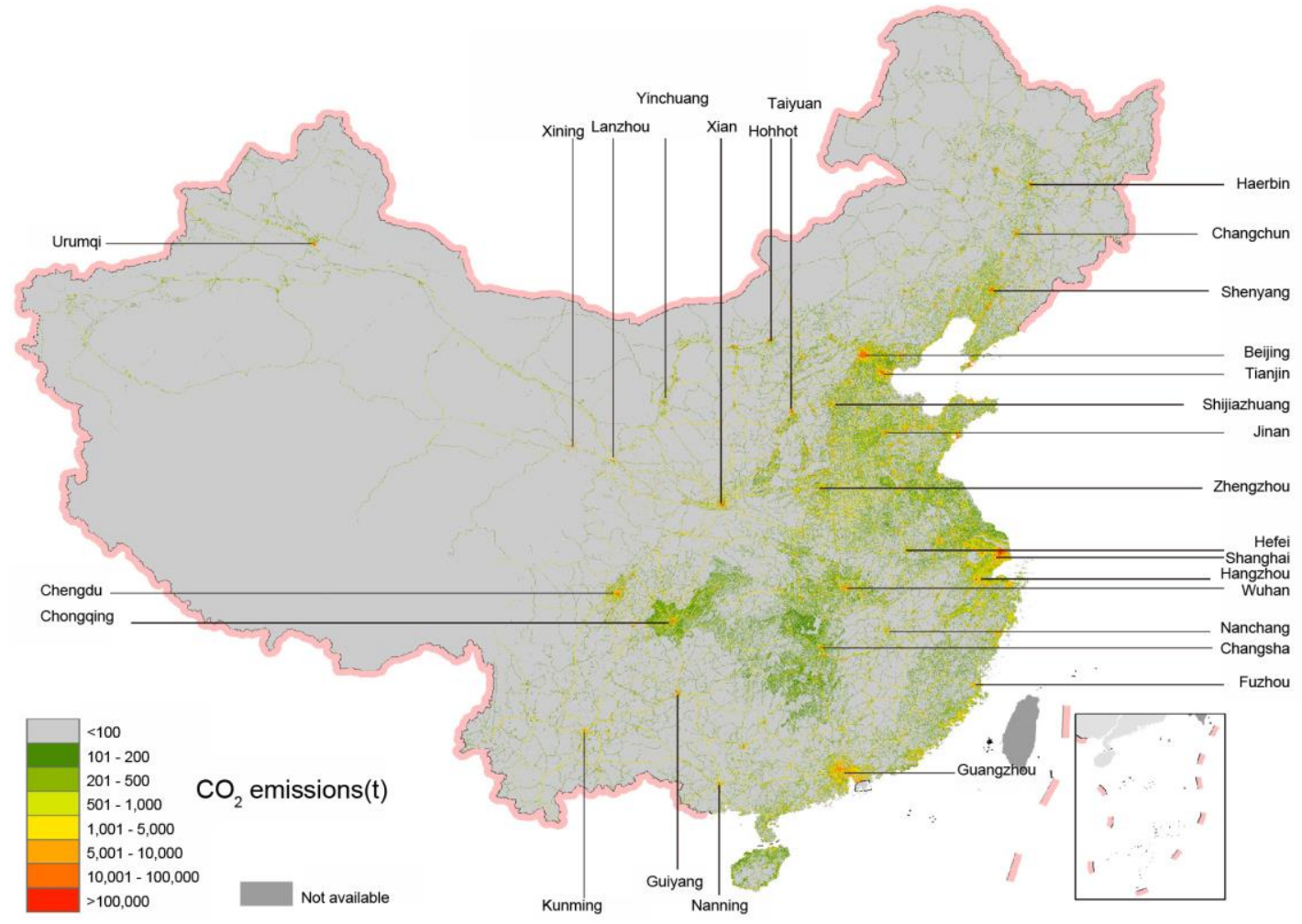

Figure 6. Comparison of $10 \mathrm{~km} \times 10 \mathrm{~km}$ resolution gridded $\mathrm{CO}_{2}$ emission map (2007) and $1 \mathrm{~km} \times 1 \mathrm{~km}$ resolution gridded $\mathrm{CO}_{2}$ emission map (2012) of China. 


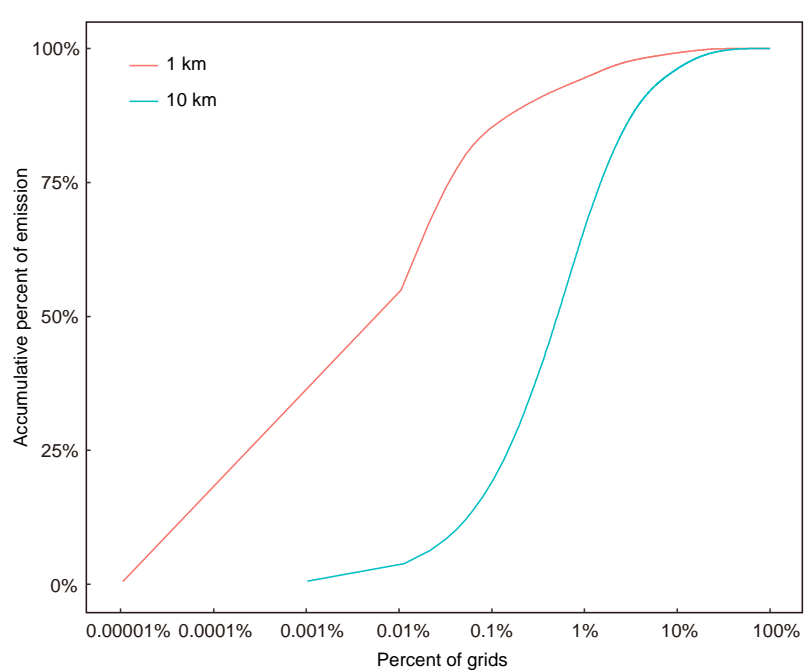

Figure 7. Comparison of cumulative percentage of grid emissions accounting for total emissions of China.

Note: The grid cells are ranked in terms of emission quantity by descending order before the cumulative percent calculation.

(a) $1 \mathrm{~km} \times 1 \mathrm{~km}$ emission maps

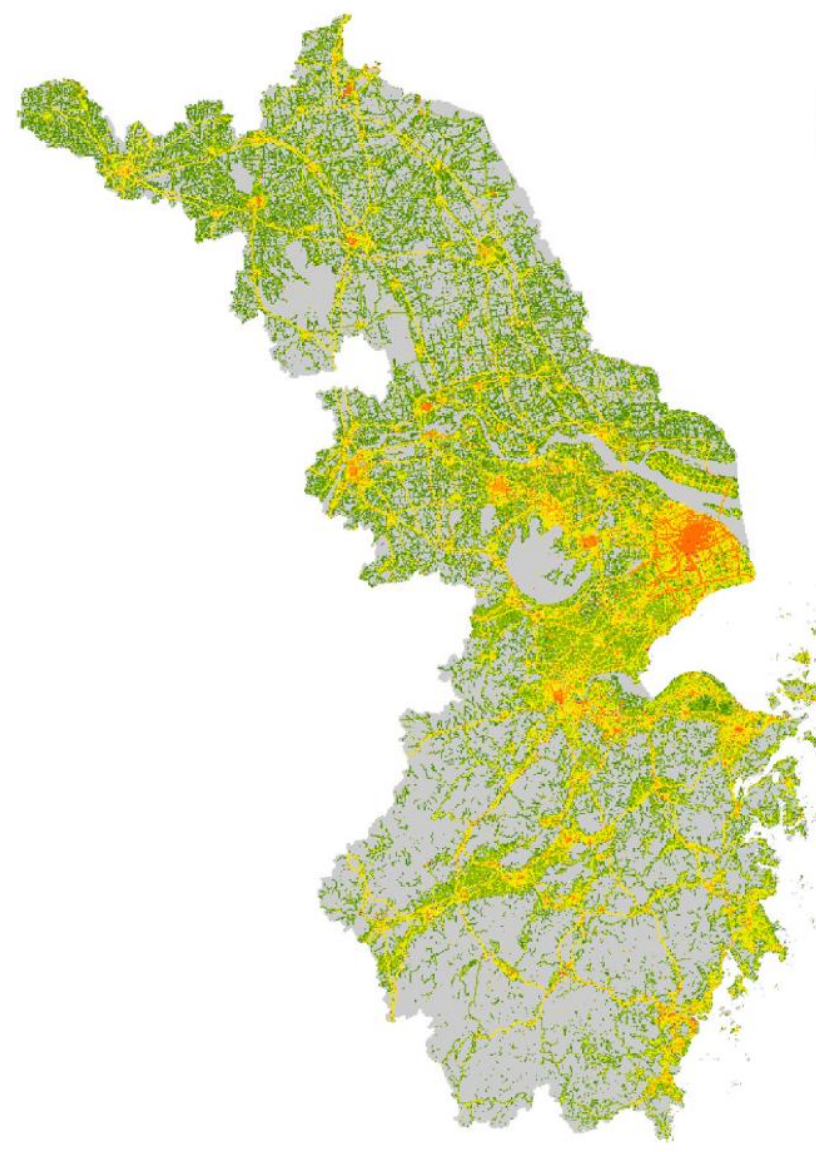

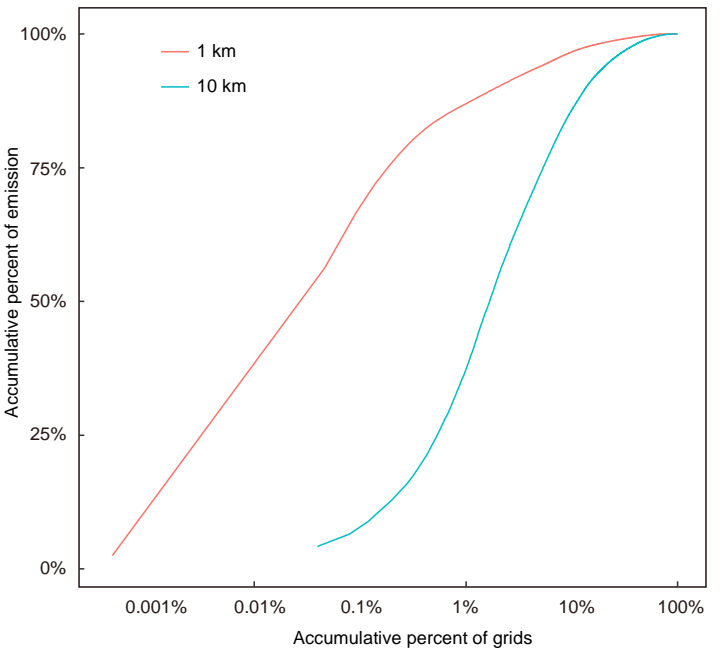

Figure 9. Comparison of cumulative percentage of grid emissions accounting for total emissions of Yangtze River Delta.

Note: The grid cells are ranked in terms of emission quantity by descending order before the cumulative percent calculation.

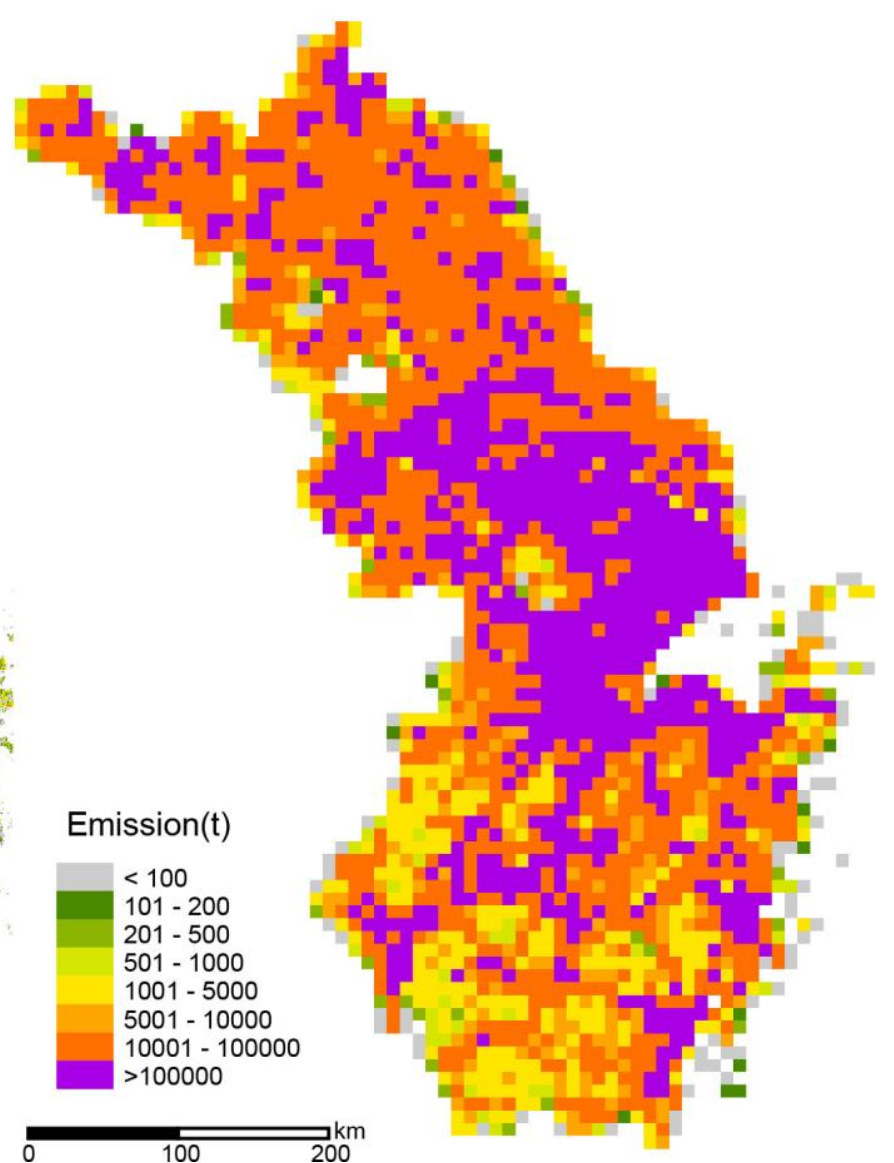

Figure 8. Comparison of the $1 \mathrm{~km} \times 1 \mathrm{~km}$ and $10 \mathrm{~km} \times 10 \mathrm{~km}$ resolution $\mathrm{CO}_{2}$ emission maps of the Yangtze River Delta. 
emissions in the Yangtze Delta where industries and business are highly developed and the spatial distribution of high emission grids are highly correlated with regional geographical characteristics (e.g., land divided intensively by lakes and waterways).

The fine resolution $\mathrm{CO}_{2}$ grids also facilitates accounting for total $\mathrm{CO}_{2}$ emissions. Total $\mathrm{CO}_{2}$ emissions, calculated from the gridded emission database, is compared with calculations from energy statistics on Shanghai, Jiangsu and Zhejiang (Cai, et al., 2015), which report differences in total emissions as $3.46 \%$ lower for Shanghai, $3.16 \%$ higher for the Jiangsu Province, and $10.78 \%$ higher for the Zhejiang Province, re-

(a) $1 \mathrm{~km} \times 1 \mathrm{~km}$ emission maps

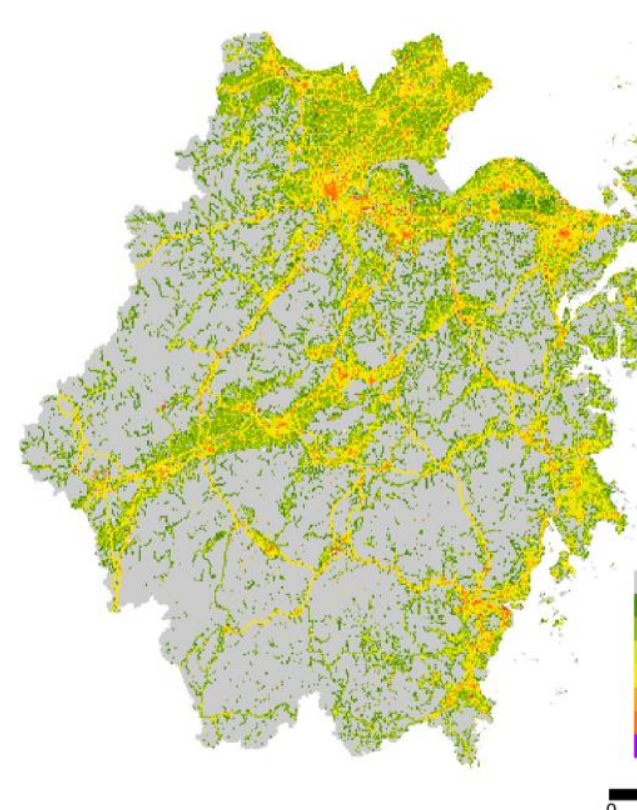

spectively. Energy use statistics for Shanghai and Jiangsu are relatively complete, which leads to much closer results for the two estimates and statistical data. The industry of Zhejiang is characterized by over 14,000 small-scale township enterprises whose energy may have been underestimated by national energy statistics that only capture enterprises with larger production. However, the high-resolution gridded $\mathrm{CO}_{2}$ emission data reflects most of the small emitters' emissions and accurate locations.

Figure 9 shows a comparison of the cumulative curves of the grid emission of Yangtze River Delta for the $1 \mathrm{~km} \times 1 \mathrm{~km}$

(b) $10 \mathrm{~km} \times 10 \mathrm{~km}$ emission maps

Emission(t)
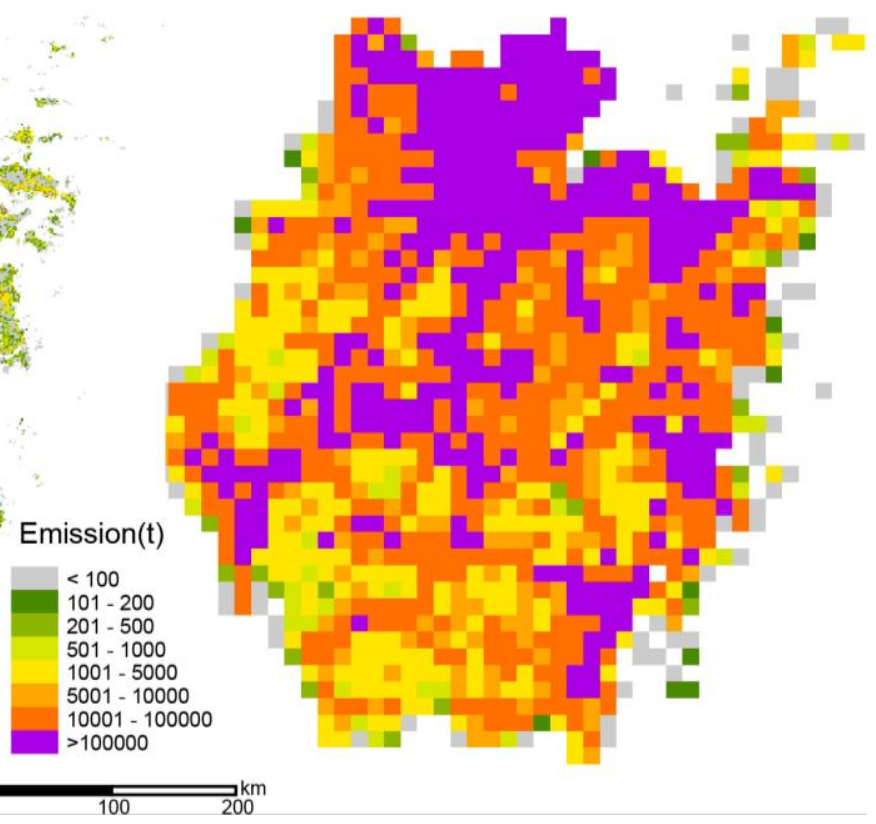

(c) Cumulative curves

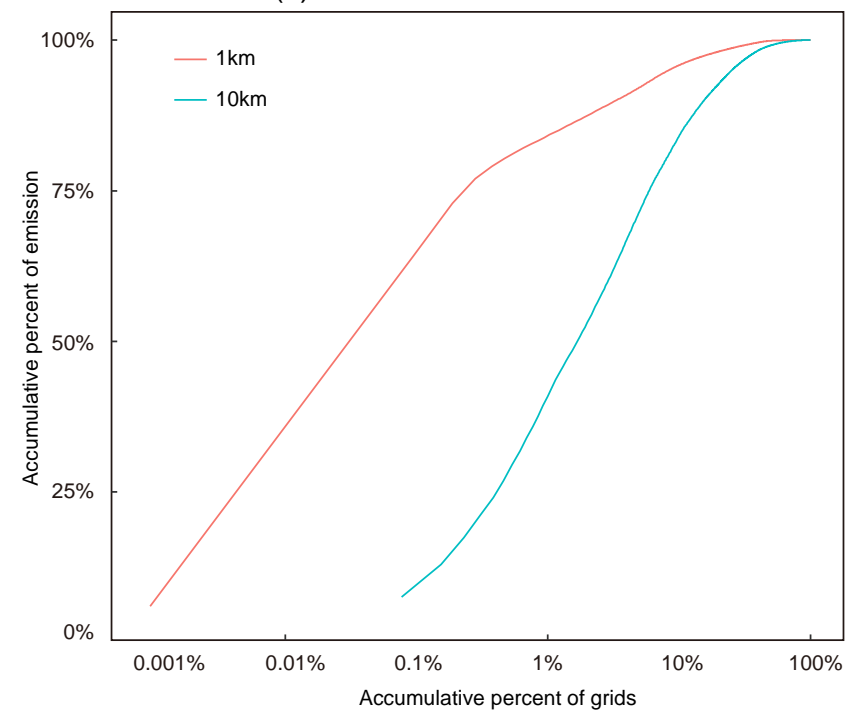

Figure 10. Comparison of the $1 \mathrm{~km} \times 1 \mathrm{~km}$ and $10 \mathrm{~km} \times 10 \mathrm{~km}$ resolution $\mathrm{CO}_{2}$ emission maps and their cumulative percentage curves of grid emissions accounting of Zhejiang Province. 
and $10 \mathrm{~km} \times 10 \mathrm{~km}$ resolution maps. The curve of the $1 \mathrm{~km} \times$ $1 \mathrm{~km}$ resolution map indicates that $1 \%$ of total land grids accounts for about $87.5 \%$ of total $\mathrm{CO}_{2}$ emissions, whereas only $37.5 \%$ is indicated by that of the $10 \mathrm{~km} \times 10 \mathrm{~km}$ resolution map. A finer resolution emission map may allow for reduced or saved supervision efforts in order to manage large proportion of emissions. This finding might foster local government departments' abilities to develop better plans for local emission reductions.

Similar observations apply to the $\mathrm{CO}_{2}$ emission distribution maps and the accumulative percentage curves of grid emissions for the Zhejiang Province. The $10 \mathrm{~km} \times 10 \mathrm{~km}$ resolution map (Figure 10 (b)) presents a general emission situation that

\section{(a) $1 \mathrm{~km} \mathrm{X1} \mathrm{km} \mathrm{emission} \mathrm{maps}$}

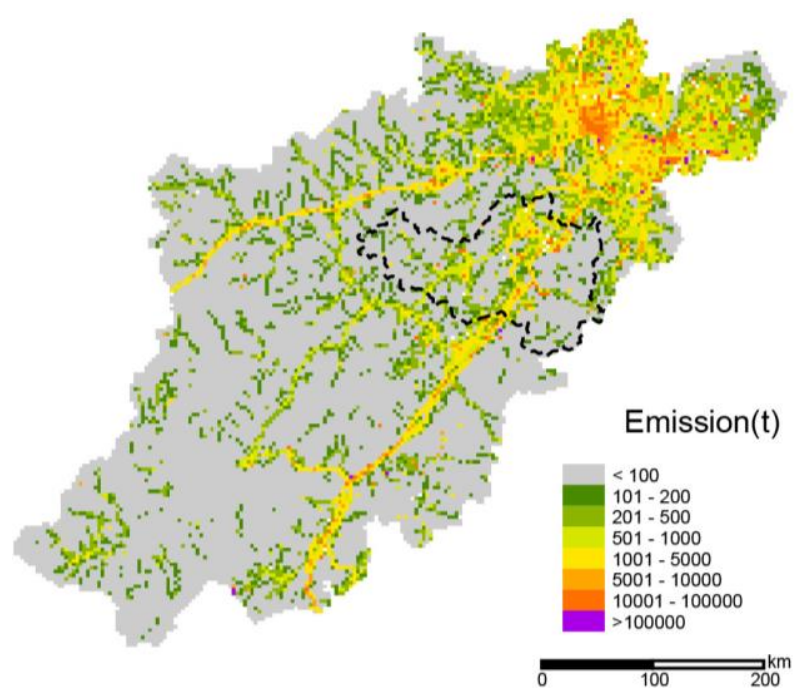

only the east-north part of Zhejiang dominates the total carbon emissions, the emission intensity decreases from north to south and from east coastal area to the west mountainous and hilly area. Additionally, this map is too coarse if one hopes to extract detailed emission information for cities such as Hangzhou City. Only the $1 \mathrm{~km} \times 1 \mathrm{~km}$ resolution map (Figure 10 (a)) can support a closer and zoom-in observation to a city or a prefecture.

3.2.3. Spatial Pattern Analysis at City and County Levels: Hangzhou and Fuyang

In terms of spatial planning and management, scaling from national down to regional (e.g., Yangtze River Delta),

\section{(b) $10 \mathrm{~km} \times 10 \mathrm{~km}$ emission maps}

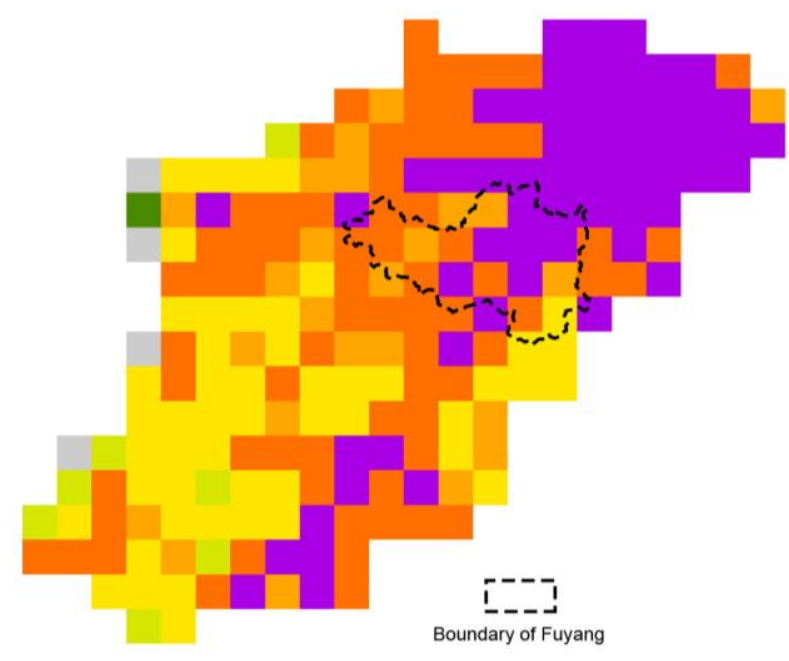

(c) Cumulative curves

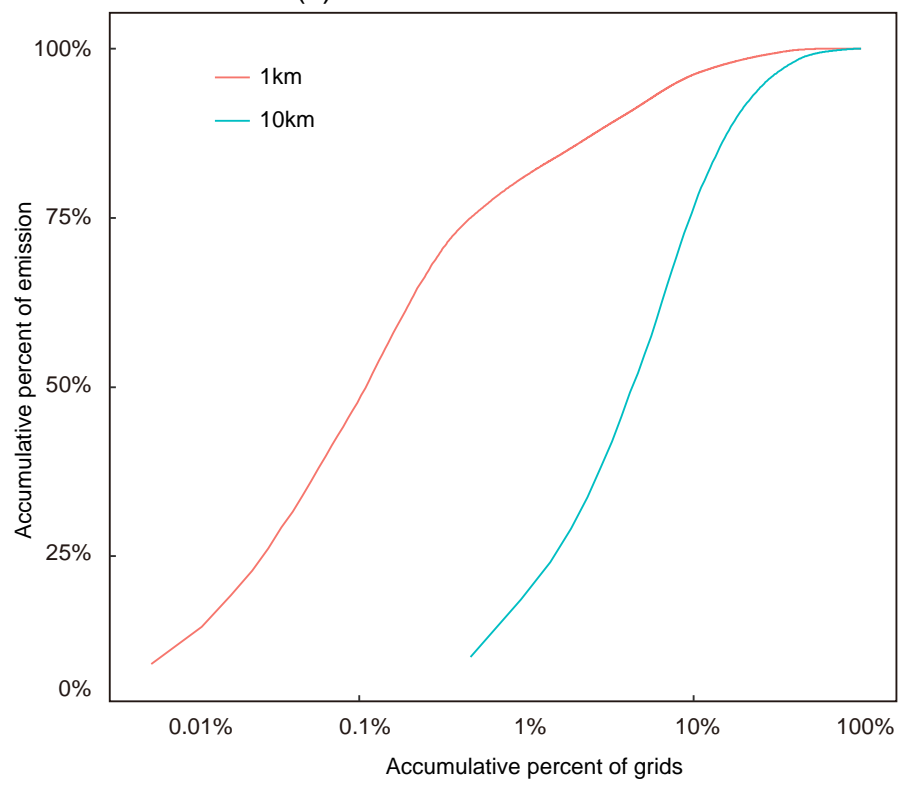

Figure 11. Comparison of the $1 \mathrm{~km} \times 1 \mathrm{~km}$ and $10 \mathrm{~km} \times 10 \mathrm{~km}$ resolution $\mathrm{CO}_{2}$ emission maps and their cumulative percentage curves of grid emissions accounting of Hangzhou City. 
provincial (e.g., Zhejiang Province) and further down to city or prefecture (e.g., Hangzhou) and to county/district (e.g., Fuyang district of Hangzhou City) level is necessary for the utility of high-resolution spatial information.

Hangzhou, the capital of Zhejiang Province is a city-level administrative unit that has a land area of $16,596 \mathrm{~km}^{2}$. In the $10 \mathrm{~km} \times 10 \mathrm{~km}$ resolution $\mathrm{CO}_{2}$ emission map, there are over 200 grids covering the entire Hangzhou city territory, which is much larger than the actual area. No clear administrative boundaries can be applied to distinct emission liability either for neighboring cities/prefectures or districts/counties. Hangzhou has 9 districts and 4 counties. When working on a local carbon reduction plan, a $10 \mathrm{~km} \times 10 \mathrm{~km}$ resolution $\mathrm{CO}_{2}$ emission map is not able to provide local spatial emission quantity accounting. However, a $1 \mathrm{~km} \times 1 \mathrm{~km}$ resolution $\mathrm{CO}_{2}$ emission map can provide richer information to describe a detailed emission distribution status. The cumulative $1 \mathrm{~km} \times 1 \mathrm{~km}$ resolution percentage curve of grid emissions accounting indicates that the regulation of $1 \%$ of Hangzhou territory is enough to manage $80 \%$ of the total carbon emission. In comparison, the information drawn from the $10 \mathrm{~km} \times 10 \mathrm{~km}$ resolution map indicates that the top $10 \%$ emission grids account for approximately $75 \%$ of total emission, which can be misleading and is far less useful for making decisions at the policy level.

The higher resolution maps indicate even stronger in the case of county- or district-level observations. For example, the Fuyang district of Hangzhou city lies in the south-west corner of urban Hangzhou, with an area of $1,831 \mathrm{~km}^{2}$. It is represented by approximately 30 grids in the $10 \mathrm{~km} \times 10 \mathrm{~km}$ resolution map, which essentially looks like a pile of colored pixels that contain little useful information. However, the 1 $\mathrm{km} \times 1 \mathrm{~km}$ resolution map shows clearly the emission boundary accurately, down to the township-, community- and even village-level.

\section{Data Quality and Uncertainty Analysis}

Though there is very limited optional approaches to examine the uncertainty of the high-resolution grid emission data, the authors have tried to control the uncertainty and guarantee the accuracy through two ways. The first is process control. The present study applied the IPCC Tier 3 level (the highest accuracy level recommended by IPCC) calculation of the point source. Emissions from industrial enterprises, or point sources, comprise the majority of $\mathrm{CO}_{2}$ emissions. The data quality of point sources was checked through cross verification, including logical analysis between different indicators and statistical analysis between facility and macro-economic data. Abnormal data were identified and revised after data verification. The accuracy of the spatial location of industrial enterprises was verified through employing dual-control of spatial accuracy of point emission sources based on both the geographic coordinates and reversed geocoding from facilities' registered addresses. High-resolution Google Earth images were used when necessary to visually reconfirm the positions of facilities with large emissions by locating the emissions stack or cooling tower.

Secondly, a comparison of the spatial data aggregation with top-down emission accounting was carried out. Considering the fact that the energy use related $\mathrm{CO}_{2}$ emission dominates total emission output, to conduct a gridded emission data quality check, the energy statistics should be taken into consideration. Beijing, Shanghai, Tianjin, Chongqing and Guangzhou have established a systematic and relatively complete energy statistic system and the energy data publication system, which contains reliable data quality. Calculated with a top-down methodology, the $\mathrm{CO}_{2}$ emission levels based on primary energy consumption in these cities can be used as reference level. Emissions calculated from $1 \mathrm{~km} \times 1 \mathrm{~km}$ resolution gridded data (a) $1 \mathrm{~km} \mathrm{X1} \mathrm{km} \mathrm{emission} \mathrm{maps}$

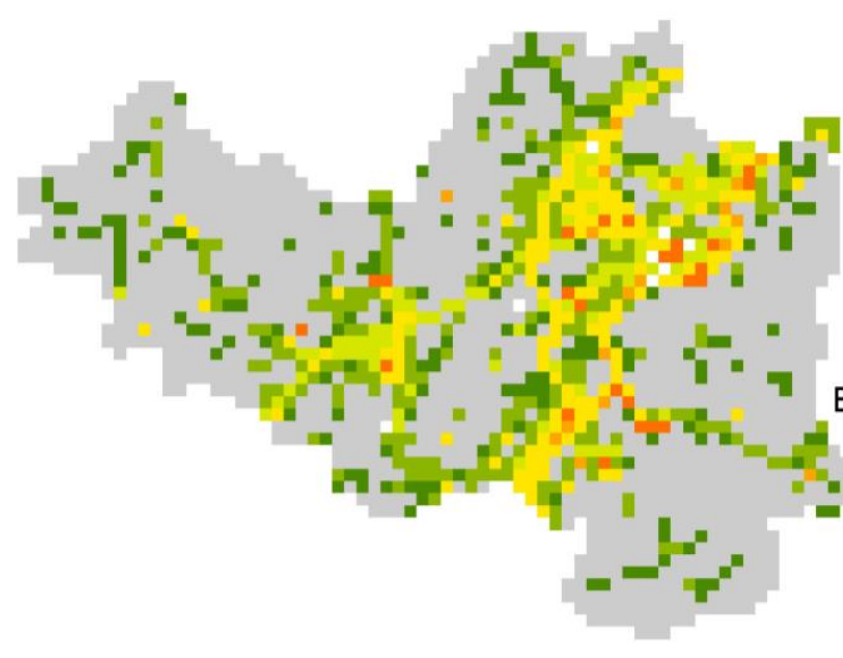

(b) $10 \mathrm{~km} \times 10 \mathrm{~km}$ emission maps

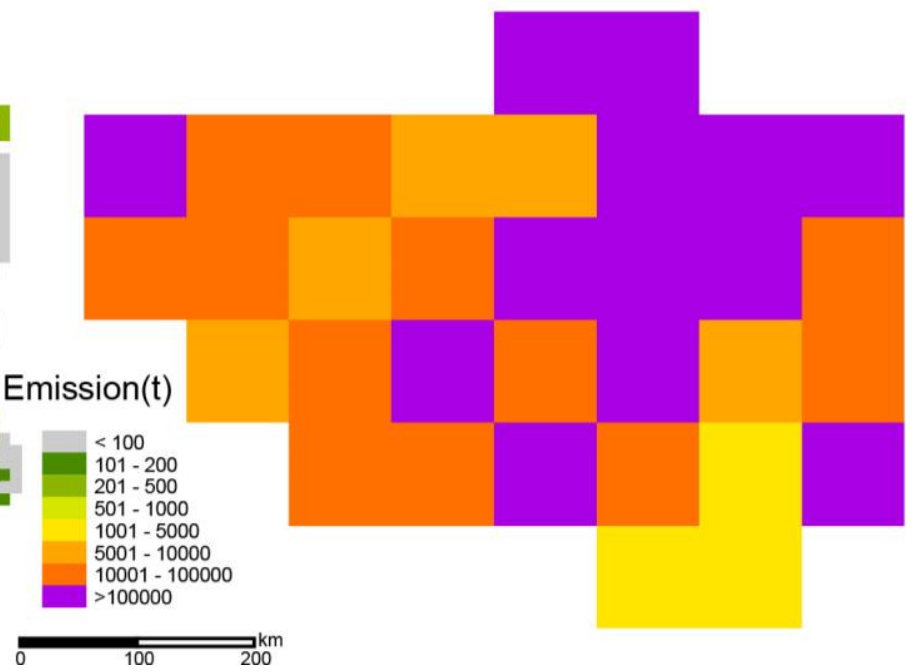

Figure 12. Comparison of the $1 \mathrm{~km} \times 1 \mathrm{~km}$ and $10 \mathrm{~km} \times 10 \mathrm{~km}$ resolution $\mathrm{CO}_{2}$ emission maps of Fuyang District, Hangzhou City. 


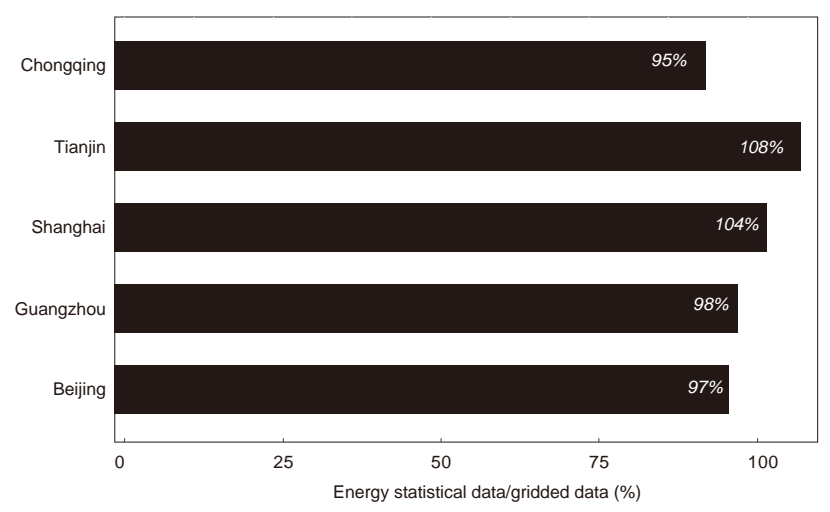

Figure 13. Comparison of $\mathrm{CO}_{2}$ emission calculated based on gridded data and energy statistics for example cities.

of example cities and from the energy statistics are compared in Figure 13. An overall consistency of the two data sets can be seen, and the data differ by 2, 3, 4 and 5\% for Guangzhou, Beijing, Shanghai and Chongqing, respectively; whereas there is a difference of $8 \%$ in Tianjin. These findings reflect the fact that $\mathrm{CO}_{2}$ emission based on gridded emission data should be viewed as being within an acceptable and realistic range.

However, there is still deficiency in the uncertainty control for the current study. In the near future, with the development of carbon concentration remote sensing satellite, and the accumulated local emission monitoring data, more approaches are expected to be available to verify and evaluate the uncertainty of spatial emission data.

\section{Conclusions}

Based on the China National Pollution Source Census (NPSC) database, which has been updated to 2012, and the CHRED 1.0, which provides $10 \times 10 \mathrm{~km}$ spatial resolution of $\mathrm{CO}_{2}$ emissions estimation of China, the CHRED 2.0 was developed to map a high-resolution $1 \times 1 \mathrm{~km}$ emission gridded database of $\mathrm{CO}_{2}$. This article elaborated the method, data foundation and its application in the spatial pattern analysis of $\mathrm{CO}_{2}$ emission for China.

For the development of the CHRED 2.0, the strict control of data quality as well as computing processes plays an important role in providing accurate data, highlighting the following four characteristics. The accuracy of computing process is strictly required. The national emission factors for the GHGs inventory and some monitoring data are used. The $\mathrm{CO}_{2}$ emissions (both from combustion of fuels and industrial processes) of each enterprise are calculated based on surveyed data. Direct verification and indirect validation of essential data, which ensures data quality. Verification and quality inspection of basic data is carried out repeatedly as well as comparison between data from different resources. $\mathrm{CO}_{2}$ emission data have been compared and verified with calculated results based on authentic energy statistic of example cities. The spatial mapping methods to formulate the grid data are drawn from the literature and have been tested and validated many times and are proved to be mature and reliable. To improve accuracy, the point emission data was checked by comparing longitudinal and latitudinal data with coordinating information based on API Geocoding.

The trial application of the CHRED 2.0 proved its superiorrity in terms of reliability and suitability for use at the macro-scale, as well as to determine provincial-, city-, prefecture- and county-level $\mathrm{CO}_{2}$ emission estimations, spatial distribution analysis and emission reduction plan making. This system's superiority is due to the accuracy of the resolution possessed by the CHRED 2.0. Thus, this system can identify the emission and can help split the data between neighbor provinces, cities or counties, accurately allocating the responsibility of emission outputs. Thus, at province-, cityand county-levels, the emission information can be correctly disclosed to the public for effective regional evaluation and emission management, and an emission reduction plan and countermeasure decisions can be made and taken into a consideration in an economically rational and viable way.

In the future, the authors will continue updating the database and providing timely and accurate carbon emission data to meet more challenging data demands.

Acknowledgments. The research was funded by the project entitled An Emission-Transport-Exposure Model Based Study on the Evaluation of the Environmental Impact of Carbon Market (No. 71673107) supported by the National Natural Science Foundation of China, and the Fundamental Research Funds for the Central Universities.

\section{References}

Andres, R.J., Boden, T.A., Bréon, F.M., Ciais, P., Davis, S., Erickson, D., Gregg, J.S., Jacobson, A., Marland, G., and Miller, J. (2012). A synthesis of carbon dioxide emissions from fossil-fuel combustion. Biogeoscien-ces, 9, 1845-1871, http://doi.org/10.5194/bg-9-18452012

Andres, R.J., Marland, G., Fung, I., and Matthews, E. (1996). A 1× 1 distribution of carbon dioxide emissions from fossil fuel consumption and cement manufacture, 1950-1990. Global Biogeochem. Cycles, 10, 419-429, http:// 10.1029/96GB01523

Asefi-Najafabady, S., Rayner, P.J., Gurney, K.R., McRobert, A., Song, Y., Coltin, K., Huang, J., Elvidge, C., and Baugh, K. (2014). A multiyear, global gridded fossil fuel $\mathrm{CO}_{2}$ emission data product: Evaluation and analysis of results. J. Geophy. Res. Atmos., 119(17), 10213-10,231, http://10.1002/2013JD-021296

Bhaduri, B., Bright, E., Coleman, P., and Urban, M. L. (2007). LandScan USA: a high-resolution geospatial and temporal modeling approach for population distribution and dynamics. GeoJournal, 69 (1-2), 103-117, https://doi.org/10.1007/s10708-007-9105-9

Cai, B. and Wang, J. (2015). Analysis of the $\mathrm{CO}_{2}$ Emission Performance of Urban Areas in Yangtze River Delta Region. China Popul. Res. Enviro., 25(10), 45-52

Cai, B., Yang, W., Cao, D., Liu, L., Zhou, Y., and Zhang, Z. (2012). Estimates of China's national and regional transport sector $\mathrm{CO}_{2}$ emissions in 2007. Energy Policy, 41, 474-483, https://doi.org/10. 1016/j.enpol.201-1.11.008

Cai, B. and Zhang, L. (2014). Urban $\mathrm{CO}_{2}$ emissions in China: Spatial boundary and performance comparison. Energy Policy, 66, 557567, https://doi.org/10.1016/j enpol.20-13.10.072

Doll, C.H., Muller, J.P., and Elvidge, C.D. (2000). Night-time Imagery as a Tool for Global Mapping of Socio-economic Parameters and Greenhouse Gas Emissions. Ambio, 29, 157-162. 
Elvidge, C.D., Hsu, F.C., Baugh, K.E., and Ghosh, T. (2014). National Trends in Satellite-Observed Lighting 1992-2012, in: Weng, Q. (Ed.), Global Urban Monitoring and Assessment through Earth Observation, pp. 97-118.

European Commission, (2015). Joint Research Centre (JRC), Netherlands Environmental Assessment Agency (PBL). Emission Database for Global Atmospheric Research (EDGAR).

Ghosh, T., Elvidge, C.D., Sutton, P.C., Baugh, K.E., Ziskin, D., and Tuttle, B.T. (2010). Creating a Global Grid of Distributed Fossil Fuel $\mathrm{CO}_{2}$ Emissions from Night-time Satellite Imagery. Energies, 3, 1895, http:// 10.3-390/en3121895

Gurney, K.R., Mendoza, D.L., Zhou, Y., Fischer, M.L., Miller, C.C., Geethakumar, S., and de la Rue du Can, S. (2009). High resolution fossil fuel combustion $\mathrm{CO}_{2}$ emission fluxes for the United States. Environ. Sci. Technol., 43, 5535-5541, http:// 10.1021/es900806c

Gurney, K.R., Razlivanov, I., Song, Y., Zhou, Y., Benes, B., and AbdulMassih, M. (2012). Quantification of fossil fuel $\mathrm{CO}_{2}$ emissions on the building/street scale for a large US City. Environ. Sci. Technol., 46, 12194-12202, http:// 10.1021/es3011282

Intergovernmental Panel on Climate Change (IPCC), 2014. Climate Change 2013: The physical science basis: Working group I contribution to the fifth assessment report of the Intergovernmental Panel on Climate Change. Cambridge University Press, London.

Kennedy, C., Steinberger, J., Gasson, B., Hansen, Y., Hillman, T., Havránek, M., Pataki, D., Phdungsilp, A., Ramaswami, A., and Mendez, G.V. (2010). Methodology for inventorying greenhouse gas emissions from global cities. Energy Policy, 38, 4828-4837, https://doi.org/10.1016/j.enpol.2009.08.050

Meng, L., Graus, W., Worrell, E., and Huang, B. (2014). Estimating $\mathrm{CO}_{2}$ (carbon dioxide) emissions at urban scales by DMSP/OLS (Defense Meteorological Satellite Program's Operational Linescan System) nighttime light imagery: Methodological challenges and a case study for China. Energy, 71, 468-478, https://doi. org/10.1016/j.energy.2014.04.103

National Development and Reform Commission, (2013). Second National Communication on Climate Change of the People's Republic of China. Beijing.

National Development and Reform Commission, (2014). The People's Republic of China National Greenhouse Gas Inventory 2005. China Environmental Science Press, Beijing.

National Development and Reform Commission, (2011). Guidelines on building GHGs emissions inventory for provinces of China. edited by NDRC. Beijing.

National Geomatics Center of China, (2014). Globe-Land30, http:// www.globallandcover.com/.

NBS and MEP, (2012, 2013, 2014, 2015). China Statistical Yearbook on Environment, 2012, China Statistical Press, Beijing.

NBS, (2015). China Energy Statistical Yearbook, 2014, China Statistics Press, Beijing.

Oda, T. and Maksyutov, S. (2010). A very high-resolution global fossil fuel $\mathrm{CO}_{2}$ emission inventory derived using a point source database and satellite observations of nighttime lights, 1980-2007. Atmos. Chem. Phys., 16307-16344, http://10.5194/acp-11-543-2011

Olivier, J.G., Janssens-Maenhout, G., and Peters, J.A. (2012). Trends in global $\mathrm{CO}_{2}$ emissions: 2012 Report. PBL Netherlands Environmental Assessment Agency Hague.

Olivier, J.G., Van Aardenne, J.A., Dentener, F.J., Pagliari, V., Ganzeveld, L.N., and Peters, J.A. (2005). Recent trends in global greenhouse gas emissions: regional trends 1970-2000 and spatial distributionof key sources in 2000. Environ. Sci., 2, 81-99, http:// dx.doi.org/10.10-80/15693430500400345

Rayner, P.J., Raupach, M.R., Paget, M., Peylin, P., and Koffi, E. (2010). A new global gridded data set of $\mathrm{CO}_{2}$ emissions from fossil fuel combustion: Methodology and evaluation. J. Geophys. Res. Atmos., 115, 1485-1490, http://10.1029/2009JD013439

van Vuuren, D.P., Smith, S.J., and Riahi, K. (2010). Downscaling socioeconomic and emissions scenarios for global environmental change research: a review. Clim. Change, 1, 393-404, http://10.10 $02 /$ wcc. 50

Wang, H., Zhang, R., Liu, M., and Bi, J. (2012). The carbon emissions of Chinese cities. Atmos. Chem. Phys., 12, 6197-6206, http:// 10.5194/ acpd-12-7985-2012

Wang, J., Cai, B., Zhang, L., Cao, D., Liu, L., Zhou, Y., Zhang, Z., and Xue, W. (2014). High resolution carbon dioxide emission gridded data for China derived from point sources. Enviro. Sci. Technol., 48, 7085-7093, http://10.1021/es405369r

Zhao, Y., Nielsen, C.P., and McElroy, M.B. (2012). China's $\mathrm{CO}_{2}$ emissions estimated from the bottom up: recent trends, spatial distributions, and quantification of uncertainties. Atmos. Environ., 59, 214-223, https://d-oi.org/10.1016/j.atmosenv.2012.05.027

Zhao, Y., Wang, S., Duan, L., Lei, Y., Cao, P., and Hao, J. (2008). Primary air pollutant emissions of coal-fired power plants in China: Current status and future prediction. Atmos. Environ., 42, 84428452, https: //doi.org/10.1016/j.atmosenv.2008.08.021 